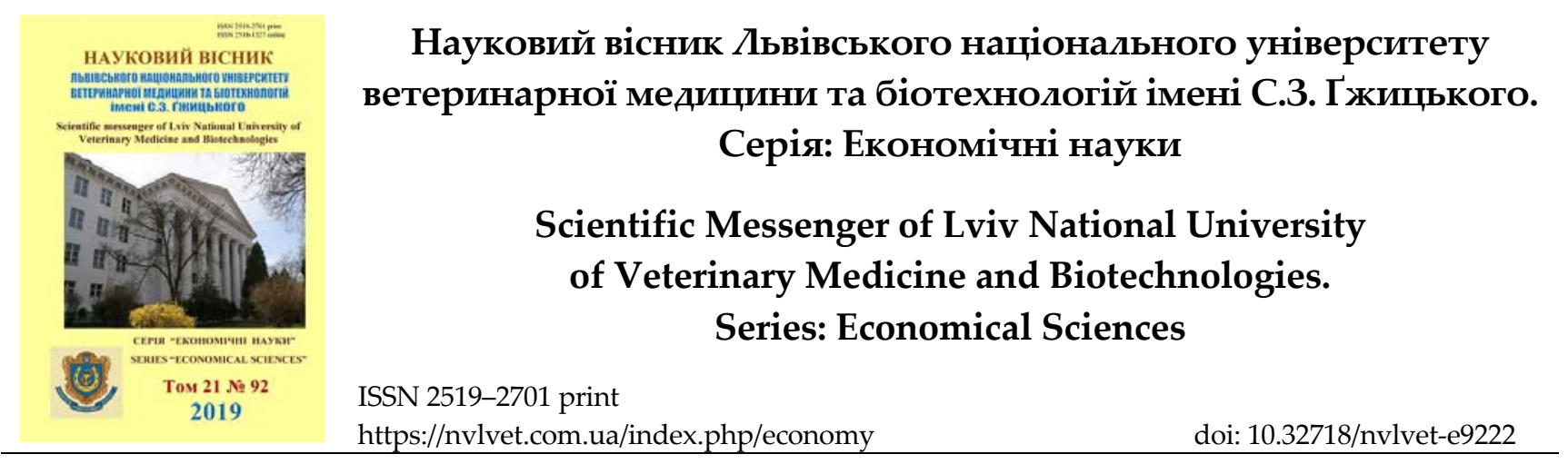

UDC 349.422.2:338.5

\title{
Market-oriented model of organization of agricultural services, non-profit cooperatives for the use of dairy resources
}

\author{
V.O. Gorbanyuk \\ Scientist agronomist economist, researcher
}

Article info

Received 11.02.2019 Received in revised form 14.03.2019

Accepted 15.03.2019

Researcher-scientist agronomist-economist, Lysenko Str., 27, Lviv 79000, Ukraine. Tel.: +38-068-42-40-344 E-mail:Lysak@i.ua
Gorbanyuk, V.O. (2019). Market-oriented model of organization of agricultural services, non-profit cooperatives for the use of dairy resources. Scientific Messenger of Lviv National University of Veterinary Medicine and Biotechnologies. Series: Economical Sciences, 21(92), 129-136. doi: $10.32718 /$ nvlvet-e9222

The strategic goal of economic and social policy in the countryside should be to ensure an integrated multifunctional development of communities, which would increase their role not only in the development of agricultural production, but also in other types of labor activities, and also, which is very important, to ensure a favorable environment for their living. Thus, the strategic foundation of this solution is the development of the productive forces of each rural community. Therefore, the orientation of the rural communities, especially the united ones, to its own resources and opportunities is the strategic basis for the revival of the Ukrainian peasantry, and given the amount of unemployed population living in rural areas today, it has a rational content. In this context, state aid could take part in the development of a Comprehensive rural development program and the revival of the peasantry, with regard to possibilities of each community, based on the new economic policy, the basis and strategic base of which should be mass co-operative movement. Due to the association of small rural producers, their contribution to the production of gross agricultural products will be significantly appreciable, so effective assistance to power structures of all levels, especially legal ones, could actually, in a short period of time, affect the increase in the profitability of their management, the creation of acceptable social conditions, improving their social protection, adapting and raising awareness of the latest technological solutions to increase their own production of cheap and quality products, as well as what is extremely important today is the improvement of the well-being of the peasants. A comprehensive, consolidated combination of the concrete efforts of the state and the resources that the rural population still possesses, in the name of its new territorial communities, under certain conditions, could become a major driving force in ensuring the systematic development and revival of the Ukrainian peasantry, which is one of the most important foundations of its existence. The modern village really needs development, and this development - financial, organizational, systemic and other forms of support. That is, there is a need for a coherent and systemic village development policy, or, as they call it European researchers, rural development policy, in our today's sense, as well as united territorial communities. Against the backdrop of a sharp rise in energy prices, agricultural machinery, fertilizers, feed, services, etc., low purchase prices, the lack of stable and reliable sales channels makes its production extremely ineffective. Solving similar issues in Ukraine is possible only with the state support for the development of agricultural servicing cooperatives as an important factor, increasing the competitiveness of private farms and individuals who are engaged in agricultural production, improving their socio-economic status and expanding their employment. The development of cooperation is a logical stage in the development of a market economy system in agriculture and one of the ways of integrated development of rural united communities. In particular, the success of rural cooperatives in Galicia in the first half of the 20th century showed a high level of adaptability of local economic traditions to European culture of agricultural production and successful agricultural business. This, extremely important for today's conditions, the experience of the survival of the Galician village until 1939, as well as the Ukrainian community abroad, showed that only uniting all the patriotic forces of the Ukrainian community and channeling their efforts to revive a solid, highly organized under the state guardianship and protection of the cooperative movement, will enable in the coming years to ensure sustainable development of rural communities and to solve problems of food security of the state.

Key words: cooperation model, organization, service, nonprofit cooperatives. 


\title{
Ринково-оріснтована модель організації сільськогосподарських обслуговуючих, неприбуткових кооперативів 3 використання молочних ресурсів
}

\author{
В.О. Горбанюк \\ Вчений агроном-економіст, дослідник, м. Львів, Украӥна
}

\begin{abstract}
Стратегічною метою економічної і соиіальної політики на селі має стати забезпечення комплексного багатофункиіонального розвитку громад, за яких би зросла їх роль не лише в розвитку сільськогосподарського виробництва, а й інших видів трудовоі діяльності, а також, що є дуже важливим, забезпечення сприятливого середовища їх проживання. При иьому, стратегічною основою вирішення иього являється розвиток продуктивних сил кожної сільської громади. Тому, орієнтація сільських громад, особливо об'єднаних, на власні ресурси і можливості являється стратегічною основою відродження украӥнського селянства, а 3 врахуванням того, яка кількість незайнятого населення проживає сьогодні в сільській місиевості, подібне має раціональний зміст. У зв'язку з иим, державна допомога могла б звестися до участі в розробиі Комплексної програми розвитку села і відродження селянства з врахуванням можливостей кожної громади, на засадах нової економічної політики, основою $і$ стратегічною базою якої мав би стати масовий кооперативний рух. Завдяки об'єднанню дрібних сільських товаровиробників, їх внесок у виробництві валової сільськогосподарської продукції буде суттєво відчутний, тому дієва допомога владних структур всіх рівнів, особливо правова, могли б реально, в короткий період часу вплинути на підвищення дохідності їх господарювання, створення прийнятних соціальних умов, поліпшення їх сочіального захисту, адаптаџї і підвищення знань щодо новітніх технологічних рімень з нарощування власного виробнищтва дешевої $і$ якісної продукиії, а також, щяо є вкрай важливо на сьогодні, це покращення добробуту селян. Всебічне, консолідоване поєднання конкретних зусиль держави і ресурсів, якими ще володіє сільське населення, в особі їі нових територіальних громад, при певних умовах, могли б стати великою рушійною силою в забезпеченні системного розвитку і відродження украӥнського селянства, що є однією з найважливіших основ його існування. Сучасне село, насправді потребує розвитку, а цей розвиток-фінансової, організаційної, системної та інших форм підтримки. Тобто, існує потреба иілісної та системної політики розвитку села, або, як називають ї̈ європейські науковиі, політики розвитку сільських територій, в нашому сьогоднішньому розумінні, також об'єднаних територіальних громад. На фоні різкого підвищення иін на енергоносії, сільгосптехніку, добрива, корми, послуги, тощо, низьких закупівельних иін, відсутності стабільних та надійних каналів збуту продукції робить ії виробництво вкрай неефективним. Вирімення подібних питань в Україні, можливе лише за умови державної підтримки розвитку сільськогосподарських обслуговучих кооперативів, як важливого чинника, підвищення конкурентоспроможності особистих селянських господарств та фізичних осіб, які займаються сільськогосподарським виробництвом, поліпшення ӥх соиіально-економічного стану та розширення сфери їх зайнятості. Розвиток кооперачиї є логічним етапом розбудови ринкової економічної системи у сільському господарстві та одним із иляхів комплексного розвитку сільських об'єднаних громад. Зокрема, успіхи сільських кооперативів Галичини у першій половині ХХ сторіччя засвідчили високий рівень адаптованості місцевих господарських традицій до європейської культури ведення сільськогосподарського виробнищтва та успішного аграрного бізнесу. Цей, надзвичайно важливий для сьогоднішніх умов досвід виживання галиџького села до 1939 року, а також украӥнської спільноти за кордоном показав, що тільки об'єднавши всі патріотично налаштовані сили украӥнської громади і скерувавши їх зусилля на відродження суцільного, високоорганізованого під державною опікою $і$ захистом кооперативного руху, дасть можливість уже в найближчі роки забезпечити сталий розвиток сільських громад і вирімення завдань продовольчої безпеки держави.
\end{abstract}

Ключові слова: кооперація, модель, організація, обслуговуючі, неприбуткові кооперативи.

\section{Вступ}

Ситуація на внутрішньому молочному ринку України набуває ознак руйнівного характеру, споживчі можливості населення практично вичерпані (високі ціни), молокопереробні підприємства вже не спроможні нарощувати виробництво (відсутній збут), домогосподарства вже не бажають утримувати корів за рахунок власних коштів (не витребуване молоко). Низькі закупівельні ціни на молоко, яке закуповується у домогосподарствах населення і неконтрольовано завищені відпускні ціни на молочну продукцію переробних підприємств та націнки в торговій мережі, провокують стагнацію внутрішнього ринку і зростання цін на неорганізованих ринках, які в більшості наближаються до цін в супермаркетах. Купівельна спроможність громадян України не сприяє розширенню обсягів ринку молока і молочних продуктів. Панівне, монопольне положення молокопереробних підприємств і торгівлі на українському споживчому ринку в тому вигляді, якими вони $є$ сьогодні, штовхає останніх на досягнення оптимізації господарської діяльності не стільки за рахунок економії на затратах виробництва, раціонального використання його факторів, тощо, стільки за рахунок монопольного контролю і диктату цін, тобто за рахунок кінцевих Споживачів. Наслідком цього є постійне скорочення кількості дрібних виробників, міграції працездатного сільського населення з сільської місцевості, що несе значні ризики не лише для самих селян, але в цілому для агропромислового комплексу країни. іiі продовольчої безпеки. Приватний сектор, де розміщені основні обсяги виробництва продукції повсякденного споживання, практично “виштовхується" з організованого ринку продовольства і нездатний в повній мірі конкурувати на ньому без такого інструменту, домінуючого в світовій і європейських практиках, як сільськогосподарська обслуговуюча неприбуткова кооперація. Особливо негативним фактором цих процесів $є$ також те, що всі ланки молочного продуктового підкомплексу, які знаходяться над товаровиробником зацікавлені в одержанні максимальної долі прибутків, ні хто в повній мірі не буде займатися проблемами сільського населення, яке виробляє стратегічний для життя, молочний продукт. Ланцюг руху молока від лану і ферми до столу Споживача залишається і надалі з розір- 
ваними інтересами його учасників, а це не може продовжуватися без значної шкоди для всіх. Така політика держави не створює умови для нарощування обсягів виробництва сільськогосподарської продукції в малих формах господарювання, до яких відносяться домо- і фермерські господарства фізичні особи, перешкоджає їх об'єднанню у обслуговуючі неприбуткові кооперативи. В результаті обсяги надходження продукції на переробні підприємства від таких товаровиробників зменшуються, формуються непрозорі схеми iii реалізації. Простежується тенденція збільшення частки домогосподарств, що займаються виключно не сільськогосподарською діяльністю, або тих, що лише частково поєднують цей вид діяльності 3 іншими (трудова міграція, сезонні промисли, тимчасові послуги, тощо). Поетапна реалізація заходів по створенню суцільного кооперативного руху в сільській місцевості (як одного із реальних шляхів вирішення проблеми) сприятиме становленню ефектнішого сільськогосподарського виробництва, де підприємницький інтерес складатиме основу економічної мотивації, а інноваційна модель розвитку стане рушійною силою економічного зростання. Завданням надзвичайної ваги сьогодення $є$ визначення наявного потенціалу фермерських та особистих селянських господарств i напрямків його використання, залучення можливостей територіальних сільських громад з метою спільного врегулювання соціальних проблем. Тому, сьогодні, як ніколи, важливо залучити невичерпну ініціативу і потенціал сільських територіальних громад, задіяти усі політичні важелі та правові механізми впровадження цього напрямку аграрної політики місцевими органами влади та органами місцевого самоврядування 3 метою пришвидшення розвитку i підвищення ефективності національної економіки України.

Мета роботи - обгрунтувати, що ж заважає кооперативній ідеї розкрити свій потенціал в Україні, країні з багатим історичним досвідом розвитку кооперації та іншими необхідними політичними, економічними й соціальними умовами поширення кооперативних організацій.

\section{Матеріали і методи досліджень}

В дослідженнях використовуються економічні, маркетингові, аналітичні, математичні, порівняльні та статистичні методи. Для оцінки актуальності досліджень використовувались публікації вітчизняних та зарубіжних вчених, статистичні звіти та результати власних досліджень.

\section{Результати та їх обговорення}

Організаційно-правовий аспект процесу розвитку сільськогосподарської кооперації в період докорінних ринкових трансформацій аграрного сектора України. Результати, висвітлені в даній статті, отримані у результаті багаторічних теоретичних досліджень, вивченні зарубіжного досвіду кооперації, а головне узагальнення діяльності зі створення i підтримки життєдіяльності кооперативних структур розвинутих країн світу і Свропи. Фундаментальним методологіч- ним принципом цього дослідження $є$ орієнтація на радикальні економічні зміни в сільському господарстві, що базуються на кооперативній ідеї. Зокрема, кооперативи розглядаються, як обов'язкова складова ринкової економічної системи і демократичного суспільства. Емпіричні підтвердження отримані завдяки використанню статистичних даних, експертних оцінок, абстрактних моделей та монографічних спостережень із застосуванням елементів правового аналізу.

В дослідженнях є оцінювали теперішній стан та обгрунтовували напрямки покращення розвитку галузі молочного скотарства в Україні. Об'єктом дослідження виступають проблеми розвитку виробництва продукції молочного скотарства в домогосподарствах населення, де сьогодні знаходиться більше 70 відсотків поголів'я молочних корів і втрата цього ресурсу може спровокувати вкрай небажані наслідки в українському суспільстві. Ситуація, в молочному тваринництві населення України потребує глибокого, осмисленого аналізу, а також причин і пошуків шляхів виходу із незадовільного становища в якому, на жаль, опинилося українське село. На мою думку, виходячи із об'єктивних причин незадовільного стану справ в українському селі $\epsilon$ відсутність європейського бачення розвитку кооперативного руху, його обов'язкової участі в ринковій багатоукладній економіці, а також відсутності державного впливу на процеси ціноутворення, як на закупівлі молока від корів населення, так і в торгівельних установах і на неорганізованих ринках. Іншою важливою причиною $є$ те, що серед багатьох вчених і практиків не має цілісної уяви про те, якою повинна бути інфраструктурна модель побудови кооперативного руху, а також, яким шляхом розвивати молочне тваринництво України, чи через розвиток виробництва продукції молочного скотарства в інтегрованих агроформуваннях, чи в повній мірі задіяти потенційні сільських об'єднаних територіальних громад, чи створити оптимальні умови розвитку, як для одних так і інших, виходячи з досвіду і практики розвинутих країн світу і Свропи. 3 врахуванням обов'язкового вирішення питань об'єктивного ціноутворення на молочну продукцію, яка закупляється молокопереробними і закупівельними організаціями від корів населення, на мою думку важливе значення має організаційна структура побудови перспективних моделей розвитку кооперативного руху в Україні. Проведеними дослідженнями з врахуванням відповідного досвіду створення і функціонування відповідних кооперативних утворень, які діяли в свій час на території Галичини, а також розвинутих країн світу і Свропи, зокрема США, Канади, Німеччини, Франції, Голландії, Ізраїлю, Польщі розроблені і пропонуються до створення багатофункціональні, 3-х рівневі для районів, 4-х рівневі для областей і 5-ти рівневі для України, інтегровані, неприбуткові, сільськогосподарські обслуговуючі структури кооперативного типу (БІНСОКи), які б могли об'єднувати значні території і кількість членів, а в перспективі створювати потужну заготівельну, переробну і збутову інфраструктуру, стати повноцінними ринковими гравцями, здатними забезпечувати ефективну конкуренцію посередницьким і монополізованим структурам. Практичний дос- 
від мені підказує, що найбільш вдалим для малих форм господарювання в регіонах України було б створення великих кластерних кооперативних утворень з розподілом на під-кластери, які б охоплювали 15-30 населених пунктів, в тому числі з міським населенням (споживачами виробленої сільськогосподарської продукції), 25-30 тисячами сільськогосподарських угідь 3 окремими структурами та відповідними органами управління територіальними виробничо-господарськими і соціально-економічними процесами. Особливістю таких кооперативних кластерів мав би бути регіональний принцип їх створення, в яких малі і середні форми господарювання (домогосподарства населення, фермерські та інші господарські виробничі одиниці) за рахунок використання наявних земельних, трудових, інтелектуальних, фінансових i інших ресурсів могли б створити в перспективі потужні виробничо-споживчі, аграрно-промислові і збутові підрозділи (відомий позитивний досвід ізраїльських кібуц). Загалом кластерна модель і вдале регіональне розташування сільськогосподарських товаровиробників 3 врахуванням тієї кількості продукції, яку вони сьогодні виробляють і могли б виробляти в перспективі, дозволить вирішити такі стратегічні завдання, як використання конкурентних переваг і швидкого нарощування ефективності суспільного виробництва. Досліджена і пропонована до розгляду модель багатофункціонального, інтегрованого, неприбуткового сільськогосподарського обслуговуючого кооперативу (кооперативного об'єднання, народного кооператив- ного підприємства, тощо) на рівні району, з врахуванням світового досвіду і практики, дозволяє за рахунок 2-3 інтегрованих кооперативів в складі 15-30 і більше кооперативних філіалів, на самоокупних госпрозрахункових принципах, які можуть бути їх прямими Засновниками, створити одне кооперативне об'єднання (підприємство) 3 власним фінансоворозрахунковим центром (філіалом обласного кооперативного банку), кредитною і страховою організаційними структурами, із залученням фермерських господарств, які по відношенню до домогосподарств - членів мають вищий господарський i економічний, a також, організаційний статус $з$ наданням в перспективі можливості їх керівникам ставати асоційованими членами і виконавчими директорами цих підрозділів, об'єднати значні території, сільські громади і їх ресурсний потенціал для створення потужних кластерних утворень, які б були здатні забезпечувати ефективну діяльність, сприяти економічній самоорганізації населення, формуванню багатоукладної економіки, становленню внутрішнього ринку, відродженню села через розвиток сімейних ферм, розширенню міжнародного кооперативного співробітництва і міжнародної інтеграції. Виконання таких складних завдань слід пов'язувати 3 проведенням ефективної політики для створення моделі ринково-орієнтованої кооперації, що базується на міжнародних кооперативних принципах у поєднанні з ринковими компонентами, формами господарювання і механізмами функціонування.

\title{
Оптимальна модель
}

використання молочних (i інших) ресурсів територіальних об’єднаних громад через створення і діяльність багатофункціональних інтегрованих неприбуткових сільськогосподарських обслуговуючих кооперативів.

\section{3-й рівень}

Районне(міжрайонне) кооперативне об’єднання

а) кількість членів - від 3 до 10 тисяч і більше, асоційованих членів - від 5 тисяч і більше.

Засновники: 2-3 багатофункціональних інтегрованих неприбуткових сільськогосподарських обслуговуючих кооперативи 2-го рівня.

$$
\text { Р а д } \mathbf{a}
$$

Асоційовані члени

Асоційовані члени

\author{
Повноцінний апарат управління \\ П Р А В Л І Н Н Я \\ Страхова \\ компанія- \\ філіал ЗУКЗІБ філіал
}

Наглядова рада Ревізійна комісія

Ф Р Ц- (внутрішній банк), філіал ЗУКЗГБ

Кредитна
спілка-
філіал ЗУКЗІБ

\author{
Юридично-ревізійна служба - \\ філіал Львівської обласної \\ асоціації обслуговуючих кооперативів \\ Позадержавний пенсійний фонд - філіал ЗУКЗІБ \\ 2-й рівень в складі: \\ 2-3 зональних(територіальних) багатофункціональних інтегрованих неприбуткових \\ сільськогосподарських обслуговуючих кооперативів. \\ Фермерське господарство - Фермерське господарство - Фермерське господарство- \\ інтегратор \\ (БШСОК) \\ інтегратор \\ (БIНСОК) \\ інтегратор \\ (БIHCOK) \\ Збори уповноважених \\ Правління
}

Районний(міжрайонний) торговий дім -

Львівської обласної асоціації обслуговуючих кооперативів 


\section{Наглядова рада Ревізійна комісія \\ Виконавчий директор \\ Апарат управління}

Кількість членів - від 1500 до 3000 і більше, асоційованих членів - від можливостей

1-й рівень(філіальний),

в складі 10-15 і більше філіалів, які охоплюватимуть від 50-100-150 і більше члені в товаро- виробників, фізичних і юридичних осіб в складі об'єднаних територіальних громад із залученням на правах асоційованих членів фермерських господарств.

$$
\begin{aligned}
& 10-15 \text { і більше } \\
& \text { фермерських }
\end{aligned}
$$

господарств - асоційованих

членів

\section{0-15 і більше \\ філіалів БІНСОКів}

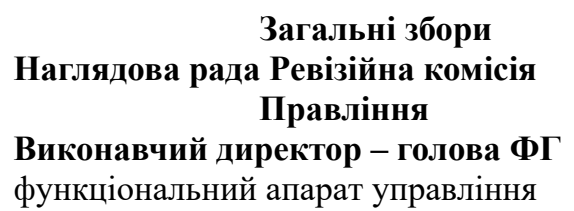

Пропонована побудова районного (міжрайонного) кооперативного об'сднання дозволяс:

а) на першому рівні раціонально поєднати існуючі ресурси (природні, трудові і матеріальні) сільських об'єднаних територіальних громад, раціонально використати кадровий потенціал, максимально охопити різних по складу товаровиробників сільськогосподарської та іншої продукції і послуг, направити їх зусилля на досягнення максимальних результатів у підвищенні ефективності суспільного виробництва;

б) на другому рівні його побудови створити багатофункціональні інтегровані неприбуткові сільськогосподарські обслуговуючі кооперативи фермерського типу, що створюють умови наближення до європейських моделей кооперативних утворень;

в) на третьому рівні створити оптимальні управлінські структури, які б на госпрозрахункових умовах оплати праці змушені будуть ефективно займатися управлінськими, постачальницькими, обслуговуючими та іншими функціями для забезпечення ефективної діяльності кооперативних структур на місцях і їх розвиток в сторону вертикальної, по американській термінології «вперед» інтегрованої побудови кооперативного руху в Україні з врахуванням практики і досвіду високорозвинутих країн світу і Європи. Госпрозрахункові філіали в умовах України з повноцінним бюджетом витрат і чековою формою контролю (50 відсотків економії у вигляді доплат розподілялися б між працюючими по наслідках господарської діяльності), головний шлях до створення великих інтегрованих кооперативних структур. Це дало б можливість мати в кожному районі 30-60 кооперативних філіалів першого рівня по кількості населених пунктів, 2-3 багатофункціональних, інтегрованих, неприбуткових обслуговуючих кооперативів другого рівня і одне кооперативне об'єднання (підприємство) третього рівня. На рівні областей, четвертий рівень, в складі засновників, районних кооперативних об'єднань (підприємств) потрібно було б створити високоефективну управлінську структуру в складі аграрного кооперативного балку, засновники фінансово-розрахункові центри кооперативних об'єднань (підприємств) третього рівня, відповідні страхові, постачальницькі, господарсько-дорадчі, юридично-правовові, ревізійні і інші органи, які б на госпрозрахункових засадах могли здійснювати вертикальне ефективне управління кооперативною діяльністю на місцях, а також використовувати наявний кадровий потенціал, існуючі ресурси сільських територій і громад областей України.

\section{Четвертий рівень (обласний, міжобласний) \\ обласна асоціація обслуговуючих кооперативів Збори уповноважених представників}

Наглядова рада з уповноважених представників

\author{
Західно-український \\ кооперативний \\ земельно-іпотечний Банк \\ (засновників 20 районних ФРЦ)
}

\author{
ПРЕЗИДІЯ \\ Голова президії - \\ Президент \\ Повноцінний \\ апарат управління \\ в складі:
}

Ревізійна комісія з уповноважених представників

Західно-українська кооперативна торгово-фондова БІРЖА

Львівський кооперативний торговий дім (20 районних коо-домів)

(агрономічної, зооветеринарной інженерної і матеріатьно-технічного постачання, харчової і переробної промисловості, бухгалтерської і економічно-аналітичної, техніки безпеки і охорони праці, санітарно-екологічної, науки і впровадження, зовнішньо-економічних зв'язків, контрольно-ревізійної служб, тощо).

БІНСОК - інтегратор, за рахунок своїх філіалів (перший рівень), в тому числі фермерських господарств - асоційованих членів в кількості 15-30, могли б забезпечувати пряме охоплення 2-3 і більше тисяч членів (по 50-100-150 у філіалі), що дало б реальну можливість, створити на другому рівні побудови 
кооперації в районі, потужного ринкового гравця, який би оперував значною кількістю товарів і наданих послуг. При цьому, фермерське господарство - асоційований член, в особі виконавчого директора, одержує реальну можливісгь для особистого розвитку за рахунок зростаючих об'ємів робіт і послуг, які воно в змозі буде надавати членам кооперативу, за що буде одержувати відповідні розрахунки, в тому числі кооперативні виплати по закінченню господарського року в сумі до 20 відсотків одержаних кооперативом пасивних доходів згідно рішень Загальних зборів, які по існуючому в Україні законодавству, не обкладаються податками. Для того, щоб органічно об'єднати інтереси членів кооперативів і асоційованих членів фермерських господарств, бажано було б, щоб його голова ставав найнятим виконавчим директором кооперативу, контроль за його діяльністю здійснювали б його Загальні збори, правління, наглядова рада і ревізійна комісія. Такий підхід давав би можливість за рахунок спільних інтересів до прискореного інтеграційного розвитку, створити відповідні продуктивні сили і сільську інфраструктуру, не витрачаючи лишніх коштів на придбання тих засобів виробництва які вже є у фермерських господарствах. Другою проблемою, на яку я б хотів звернути особливу увагу $є$ питання ціноутворення, без позитивного вирішення якого відтворити європейський кооперативний рух в Україні буде не можливо і хочу продемонструвати чому? Досліджуючи природу ціноутворення в сьогоднішніх умовах, приходимо до невтішних висновків, шо останнє, якраз і с головною причиною негативних процесів, які відбуваються на молочному ринку. Iснуюча на сьогодні цінова політика на закупівлі молочної продукції від господарств населення вкрай деструктивна, повністю дискримінаційна направлена на пряме знищення мотиваційних прагнень товаровиробників займатися виробництвом і збільшувати іiі реалізацію, що прямо призвело до катастрофічних наслідків зі знищення поголів'я корів, яке продовжується і сьогодні. Для більш повного розуміння цієї ситуації наведемо декілька прикладів: місто Бар, Вінницької області, магазин "Економ" станом на 19.08-2015 року, літр молока жирністю 0,5 відсотка, ціною - 15,50 гривні, при перерахунку до базисної жирності 3,4 відсотки, по якій закупляють молоко від корів населення, ціна зростає до 105,74 гривні, а питома вага товаровиробника складає лише 3 відсотки. Цей же виробник, 11.03-2016 року, один літр молока жирністю 0,5 відсотка, ціною 18,36 гривні, при перерахунку ціна зростає до 124,85 гривень, а питома вага товаровиробника зменшується до 2,5 відсотків. 1 літр молока цієї ж жирності 03.12-2017 року, в супермаркеті "Грош-експрес" м. Бар, Вінницької області пропонувався Споживачу по ціні 26,99 гривні. В перерахунку до базисної жирності його ціна зростає до 183,53 гривні, що складає по курсу НБУ на той час 6,7 ам. долаpa, при тому, що його середньорічна закупівельна ціна від корів населення, яка діяла на той час $-4,93$ гривень за 1 літр базисної жирності, а питома вага до кінцевої ціни продаж в торгівлі лише 2,7 відсотка. Супермаркет “Метро”, 06.02-2019 року, це й же бренд, це ж молоко, 0,5 відс. жирності, ціна - 29,50 гривень, що в перерахунку до базисної жирності складає 200,60 гривень, або в перерахунку до американського долара по курсу НБУ на дану дату - 7,43 ам. долара за 1 літр, а питома вага товаровиробника при закупівельній ціні 4,68 гривень за 9-ть місяців 2018 року від кінцевої ціни продаж склала лише 2,3 відсотка. При цьому, ціни на молоко відповідної жирності на початок 2019 року в порівняні до 2015 року зросли на 90,3 відсотка, при тому, що закупівельні ціни на молоко від корів населення за цей період лигає на 64,8 відсотків з 2,84 до 4,68 (дані за 9-ть місяців 2018 року) гривень за 1 літр молока базисної жирності. Подібне становище на внутрішньому ринку можемо спостерігати і на масло тваринне, так у супермаркеті “Ашан” м. Львів, 18.01-2019 року, жирністю 82 відсотки по ціні 200 грамової пачки - 90,63 гривні, а така ж сама пачка, але 80 відсотка жирності, солоне по ціні 94,91 гривні, що по курсу до американської валюти на цей час складає, відповідно - 17,48 і 16,28 американських доларів за 1 кілограм при перерахунку до базисної жирності в Україні 82,5 відсотки. Теж саме можна сказати за супермаркет "Метро", де 06.022019 року 200 грамова пачка, 80 відс. жирності, солоне, відомого бренду коштувала 97,30 гривень, що в перерахунку на 82,5 відс. жирності ціна 1 кг - 500,16 гривень, а по курсу на відповідну дату до ам. доларастановить 18,52 долара, при тому, що по даних Української асоціації виробників молока (АВМ) європейська ціна на цей час складала 4,7-5 американських доларів за 1 кілограм. Подібних прикладів ціноутворення на молочну продукцію можна наводити безліч, але висновок тут може бути один, що все це, в кінцевому випадку лягає непосильним тягарем на купівельні можливості Споживача. А в дійсності всі говорять про низьку купівельну спроможність українського Споживача? В натурі це безконтрольна монополія посередницьких структур в умовах сьогоднішньої Української держави. 1 літр молока, базисною жирністю 3,4 відсотки ДСТУ 3662-2015 заготовленого від населення по ціні 4,93 гривні в процесі його переробки і нормалізації до відповідної жирності, дозволяє збільшувати кількість молока молокопереробними підприємствами для реалізації при: 2,5 відс. жирності до 1,36 літри; 2,0 відс. до 1,7; 1,5 відс. до 2,27; 1,0 відс. до 3,$4 ; 0,5$ відс. до 6,8 літрів. Все це дозволяє переробним i торговим підприємствам за рахунок монопольного володіння можливостями переробляти і продавати молоко без присутності на цьому ринку сильного конкурента в особі розвинутого кооперативного сектору і недостатньому впливі на ці процеси зі сторони держави, заробляти великі спекулятивні надприбутки. На жаль населення купляючи молочну продукцію в силу необізнаності не звертає на це увагу, чим успішно користуються монопольні переробні і торгові структури. Виходячи з цього, виникає цікаве запитання? Чому в демократичній, з розвинутою економікою Америці, де не впливають не ринковими методами на ціноутворення, встановлені на законодавчому рівні, обов'язкові до виконання, в ланці “товаровиробник-нереробне підприємство-торгівля" чіткі правила, яких перераховані гравці мусять дотримуватися, при тому, що питома вага кожного до кінцевої 
ціни продаж Споживачам в торгівлі складає, відповідно: 47 - 33 - 20 відсотків. Подібні підходи спостерігаються і в сусідній до нас Польщі, де частка виробника від кінцевих цін продаж складає біля 60 відсотків. При подібних підходах до встановлення цін на молочну продукцію від кінцевих продаж, останні для українських товаровиробників могли б зрости в декілька разів відповідно до сьогодні діючих. Стає зрозумілим, що вітчизняний виробник при таких цінах не тільки не вирізав би поголів'я корів, а навпаки, останнього потрібно було б зупиняти, як це відбувається в Канаді, де згідно діючого законодавства фермер, щоб ввести в стадо первістку, повинен заплатити в держбюджет 30 тисяч канадських доларів. Дехто із скептиків заперечить, що молоко від корів населення низької якості і матиме рацію, не звернувши увагу, або не розуміючи того, що у вим'ї здорової тварини, чи то на комплексі, чи в дядьківському хліві, останнє завищи стерильне i головне завдання, яке постійно стоїть перед виробником, як його таким доставити на переробку. Але на жаль молокопереробні і заготівельні організації за 27 років не спромоглися створити при допомозі держави оптимальну заготівельну інфраструктуру, яка в Україні могла б стати потужним мотиваційним фактором до зростання продуктивних, якісних і товарних характеристик виробництва молочної продукції для малих форм господарювання на селі і значного підвищення його ефективності. Якщо, на сьогодні селянин одержує від кінцевих продаж лише $2,3-2,5-3$ відсотків, а решту на шляху до Споживача, так звані посередники, то в цій ситуації ті, що виробляють молоко і ті, що його споживають, заздалегідь приречені і це являється на сьогоднішній день найголовнішим протиріччям, яке з однієї сторони призводить до знищення поголів'я корів в господарствах населення, а з іншої - до неповного забезпечення громадян України повноцінною фізіологічною нормою споживання молочних продуктів.

\section{Таблиця 1}

1. Поголів'я корів, ст. на 1.01 відповідного року, тис. голів

2. Валове виробництво молока,тис. тон

\begin{tabular}{rrrrrrrr}
\hline 2014 & 2015 & 2016 & 2017 & 2018 & 2019 &,+- & в \% \\
\hline 1979 & 1733,5 & 1668 & 1623 & 1575 & 1500 & -479 & $-24,2$ \\
8915 & 8545 & 8015 & 7676 & 7515 & 7339 & -1576 & $-17,8$ \\
1824 & 1737 & 1346 & 1198 & 1239 & 1117 & -707 & $-38,8$ \\
\hline
\end{tabular}

Такі темпи зменшення поголів'я корів і валового виробництва молока в домогосподарствах населення на фоні незначного збільшення його виробництва в сільськогосподарських підприємствах призведе прямо до продовольчої залежності від зарубіжних виробників і знищення в перспективі власного виробництва. Дослідження кореляційних взаємозв'язків показали, що між цінами на молоко, продуктивністю корів, товарністю і окупністю його виробництва існує певна об'єктивна залежність, без врахування якої зупинити негативні процеси, які відбуваються в молочному тваринництві України практично неможливо. Подібні протиріччя в суспільстві можливі у трьох випадках, а саме: відсутності належного контролю зі сторони державних органів, повного домінування монопольних структур на внутрішньому споживчому ринку (про що було сказано вище) і дієвої конкуренції зі сторони високоорганізованого кооперативного сектору економіки, який обов'язково присутній в ринковій системі розвинутих країн світу і Європи. Порушення конкурентно-ринкового механізму зумовлює невиправдане завищення цін, погіршення позицій Споживачів, особливо в сфері задоволення попиту, тому в умовах самостійності господарюючих одиниць конкуренція відіграє надзвичайно важливу роль його саморегуляції. Застійні явища в ринковій економіці триватимуть доти, поки не з'явиться на ринку сильний конкурент, який стане загрозою монопольному положенню певних великих гравців. В цьому випадку, суцільна обслуговуюча неприбуткова кооперація і є тим, сильним конкурентом, присутність якого на ринку створює конкурентне середовище, яке в змозі реально впливати на механізми ціноутворення і зменшення цінового тиску на кінцевого Споживача, що i буде слугувати реальною силою виведення українського села на шлях добробуту і багатства.

\section{Висновки}

Сприяння розвитку кооперації особистих селянських господарств $\epsilon$ необхідною умовою організаційного забезпечення соціального захисту населення на сільських територіях, реалізації його виробничого потенціалу. Водночас економічні умови, в яких формуються обслуговуючі кооперативи в Україні $є$ відмінними від тих. в яких пройшли свою еволюцію молочарські кооперативи в розвинутих країнах світу. Різними також є цілі створення такої організаційної форми, яка вимагає участі держави в даних процесах у частині інвестування в придбання (або створення) переробних потужностей та частковій передачі прав власності на них особистим селянським господарствам - учасникам кооперативів. При цьому розподіл прав власності повинен мати мотивуючий характер 3 наданням преференцій тим учасникам кооперативу, які мають більшу кількість молочного поголів'я. Це дасть змогу державі стати гравцем на ринку молочної сировини і впливати на цінову кон'юнктуру на ньому. Фактично кооперативи мають форсувати процес власного розвитку, йти шляхом акумулювання ланок у вертикальному ланцюгу формування молочної проду- 
кції, в іншому випадку - вони приречені на невдачу та недосягнення економічних i соціальних цілей, які ставлять перед собою. Проведеними дослідженнями повністю підтверджуються висновки про те, що товарність заготівель (реалізація молока з двору до виробленого) на фоні стимулюючого ціноутворення має безпосередній вплив на ефективність господарської діяльності домогосподарств населення (окупність і дохідність) і є головною відповіддю на те, що тільки масовий кооперативний рух на селі в змозі вплинути на стабілізацію тваринницької галузі в господарствах населення, забезпечення продовольчої безпеки держави і вирішення багатьох проблемних питань, які сьогодні існують в сільських територіальних громадах. В даному контексті перспективами подальших досліджень $є$ визначення етапів формування такої кооперативної системи, частки участі держави в ній та використання в законодавчому забезпеченні процесу кращого світового досвіду з регулювання створення і діяльності неприбуткових сільськогосподарських обслуговуючих кооперативів.

\section{References}

Gorbanyuk, V.O. (2018). The cooperative movement in rural areas should be a priority in reforming of agriculture (opportunities, realities and economic efficiency of its approval). Scientific Messenger of Lviv National University of Veterinary Medicine and Biotechnologies, 20(86), 28-33. doi: 10.15421/nvlvet8605.

Gorbanyuk, V.O. (2018). The serving nonprofit cooperation and optimal pricing - the priority of agrarian reform in dairy farming of rural households in Ukraine. Scientific Messenger of Lviv National University of Veterinary
Medicine and Biotechnologies, 20(91), 66-73. doi: 10.32718/nvlvet9114.

Horbaniuk, V.O., \& Lysak, O.I. (2012). Resursni mozhlyvosti stvorennia molochnykh kooperatyviv $\mathrm{v}$ rehioni. stor. Lvivskyi natsionalnyi universytet veterynarnoi medytsyny ta biotekhnolohii imeni S.Z. Hzhytskoho. Rozvytok silskykh terytorii, silskohospodarska kooperatsiia. Vydavnytstvo "Spodom" (in Ukrainian).

Horbaniuk, V.O., Sedilo, H.M., Kostyrko, I.H. (1988). Ahropromyslovyi kombinat "Dnister", pershi naslidky, problemy, shliakhy vyrishennia. K., Vydavnytstvo "Urozhai" (in Ukrainian).

Kostiuk, M.D., Muzyka, P.M., Dumanskyi, A.Ia., Iiankiv, I.Ia., \& Solomonko, D.O. (2012). Silskohospodarska kooperatsiia v Halychyni: istoriia, sutnist, perspektyvy. Naukovo-praktychnyi posibnyk. Vydavnytstvo "Spolom" (in Ukrainian).

Zinovchuk ,V.V. (2012). Orhanizatsiino-pravovi zasady stanovlennia silskohospodarskoi kooperatsii v Ukraini. Visnyk Zhytomyrskoho natsionalnoho ahroekolohichnoho universytetu, 1(2), 3-12. http://nbuv.gov.ua/UJRN/Vzhnau_2012_1\%282\%29_ 3 (in Ukrainian).

Zinovchuk, V.V. (2001). Orhanizatsiini osnovy silskohospodarskoho kooperatyvu. K. Lohos (in Ukrainian).

Zinovchuk, V.V. (2010). Ekonomichna pryroda psevdokooperatyviv ta nebezpeka yikh poshyrennia $\mathrm{V}$ ahrarnomu sektori Ukrainy. Naukovyi visnyk Poltavskoho universytetu spozhyvchoi kooperatsii Ukrainy, $3, \quad 23-28$. http://nbuv.gov.ua/UJRN/Nvpusk_2010_3_5 (in Ukrainian). 